\title{
THE TRANSCENDENCE OF THE EGO IN CONTINENTAL PHILOSOPHY - CONVERGENCES AND DIVERGENCES
}

\author{
STATHIS LIVADAS
}

$\mathrm{PhD}$ in the Philosophy of Mathematics, Independent Scholar. University of Patras, Department of Mathematics. 26504 Rion Patras, Greece.

E-mail: livadasstathis@gmail.com

This article deals with a core matter of continental philosophy which is the nature of the ego taken as a concept originating in the subjective idealism of the German school of the early nineteenth century and further developed in its various ramifications throughout the twentieth century. The main philosophical positions I will discuss are Husserl's phenomenology of the ego in his later transcendental phase, the Heideggerean view of the nature of Dasein, and Sartre's approach of the Being-for-itself as mainly exposed in Being and Nothingness. The central idea defended throughout this article is that self-constituting temporality as immanently induced may serve as a common foundation of the nature of the transcendental ego both in the Husserlian phenomenology and in the Heideggerean and Sartrean alternative positions; further, I will hold that, as consequence, the ultimate question about the possibility of an ontology of the pure ego is transposed to the question of the origin and foundation of inner temporality. Yet, in this case one is set to face anew the circularity of an infinite regression in terms of reflecting-reflected and the inevitability of the subjective character of the origin of temporality. Besides this key question-a primary issue of this article-I will address the issue of the convergences and differences regarding aspects of the essential nature of the Husserlian ego, the Heideggerean Dasein, and the Sartrean Being-for-itself, especially regarding the widely debated topic of the 'exteriority' of the latter two 'egological' concepts with regard to the world in contrast to the 'interiority' of the Husserlian absolute ego.

Key words: Absolute flux of consciousness, Being-for-itself, Being-in-itself, Dasein, ecstatic, infinite regression, temporal unity, transcendental ego.

(C) STATHIS LIVADAS, 2019 


\section{ТРАНСЦЕНДЕНЦИЯ ЭГО \\ В КОНТИНЕНТАЛЬНОЙ ФИЛОСОФИИ: \\ СОВПАДЕНИЯ И РАЗЛИЧИЯ}

\section{СТАФИС ЛИВАДАС}

$\mathrm{PhD}$ по философии математики, независимый исследователь.

Университет Патраса, факультет математики.

26504 Рион Патрас, Греция.

E-mail: livadasstathis@gmail.com

В статье речь идет о центральной проблеме континентальной философии, о природе эго, понятого как концепт, который возник в субъективном идеализме в немецкой школе в начале XIX столетия и который в дальнейшем был представлен в различных модификациях в XX столетии. Я собираюсь обсудить такие основные философские позиции как феноменология эго у Гуссерля в его поздний трансцендентальный период, хайдеггероский взгляд на природу Dasein, подход Сартра в отношении бытия-для-себя, разработанный в основном в «Бытии и ничто». Центральный тезис, обосновываемый в этой статье, заключается в том, что само-конституирующая темпоральность трансцендентального эго в качестве имманентного феномена может служить общим обоснованием природы трансцендентального эго как в гуссерлианской феноменологии, так и в альтернативных позициях Хайдеггера и Сартра и, таким образом, первичный вопрос о возможности онтологии чистого эго может быть переведен в плоскость ответа на вопрос о возникновении и основании внутренней временности. В этом случае мы заново сталкиваемся с цикличностью бесконечного регресса рефлектируемого-рефлектирующего и неизбежностью субъективного характера возникновения временности. Кроме этого ключевого вопроса, являющегося центральным для этой статьи, не менее важным является дискуссия по поводу совпадения и различия в отношении сущностной природы гуссерлианского эго, хайдеггерианского Dasein и сартровского бытия-для-себя, в особенности в отношении широко дискутируемой среди ученых проблемы «экстериорности» двух последних «эгологических» концепций по отношению к миру в противовес «интериорности» гуссерлианского абсолютного эго.

Ключевые слова: Абсолютный поток сознания, бытие-для-себя, бытие-в-себе, Dasein, экстатичность, бесконечный регресс, темпоральное единство, трансцендентальное эго.

\section{INTRODUCTION}

In the philosophical literature by the term continental philosophy is generally understood the European philosophy originating mainly in the subjective idealism of Fichte and Hegel which ultimately leads to the $20^{\text {th }}$ century offshoots as are thought to be, among others, the Husserlian phenomenology, the Heideggerean theory of Dasein and the Sartrean existentialism. As it is known there exist certain ramifications within the broad context of continental philosophy but in the present work I will almost exclusively refer to the philosophical theories mentioned above. In this scope 
I'll try to bring out some fundamental similarities with regard to the 'creeping' transcendence of the ego of consciousness, this latter taken as essentially temporally founded in the Sartrean, Heideggerean and Husserlian philosophical work. On this account I will deal to a significant extent with some key questions concerning the temporality and the place of the ego within the world taken in the broad sense of a primitive soil of experience. This given I will carry out a comparative review of the convergences and divergences in the respective philosophers' conception of the transcendental ego (taking into account the particular attitude of Heidegger and Sartre toward this concept), while addressing the possibility of founding an ontology of the pure ego. Concerning the Heideggerean view it might seem odd to include his approach in the same terms as with Husserl's and Sartre's, given his own basic categories and the sense he attributed to Dasein, yet as the main scope of the article is to argue for the self-constituting inner temporality as the common ground for the respective philosophical positions, I thought it especially motivating to include Heidegger's ontology of Dasein in this comparative study. In developing my argumentation I will mostly refer to the original works of the respective philosophers, namely to Husserl $(1966,1976)$, Heidegger $\left(1986^{1}, 2004\right)$ and Sartre $(1943,1960)$. Of course there exists an extensive literature on the subject matter of this article especially with regard to the nature of absolute subjectivity ${ }^{2}$. However my intention is to address issues in the secondary literature to a relatively limited extent as this would require yet another paper. Instead I will focus primarily into the original texts of the aforementioned philosophers, taking of course into account current research and the general terms of the philosophical discussion on the issue.

More specifically in Section 2 I discuss the question of an infinite regression induced by the scheme reflecting-reflected and the way it is dealt with by these philosophers, taking into account that this was a prime motivation for Husserl to seek a recourse to the absolute ego in the sense of a transcendence within the immanence of consciousness. In Section 3, I discuss the relation of the Husserlian ego with the world (in the sense of a primitive soil of experience) and the respective Heideggerean view of the presence of Dasein within the world and its relation with the world of phenomena. A special attention will be given also to the Sartrean view of the Being-

\footnotetext{
Mainly through its English translation (Heidegger, 1996).

2 One may refer indicatively to the works of R. Bernet (1994), K. Held (2007), P. Keller (1999), L. Levy (2016), P. Merlan (1947), D. Zahavi (2002, 2012); also to the collective works A Companion to Phenomenology and Existentialism (Dreyfus \& Wrathall, 2016), and Self-Awareness, Temporality, and Alterity (Zahavi, 1998).
} 
for-itself (Pour-soi), as being in the world like any other ego, thereby refuting the Husserlian position of the existence of a non-objectifiable, extraneous to the world, a-temporal ego within consciousness. In Sections 4 and 5 I will address the question of the similarities and differences in the conception respectively of the transcendental ego and of Dasein between Husserl and Heidegger and in the conception of the transcendental ego and the Being-for-itself between Husserl and Sartre. Lastly in Section 6, I'll argue that temporality can stand as a unifying pole in the foundation of the transcendental ego itself (also in its alternative versions) and in its relation to the objective world, in establishing first that inner temporality should be regarded as the ultimate essential trait of the ego in general of continental philosophy. A consistent argumentation for the central position of temporality concerning the nature of the transcendental ego should be regarded as the main focus of this paper, an intention ultimately served (often in an indirect way) by the whole discussion on the character of the continental ego.

Sartre's approach will be mainly discussed in Section 5 in which case the ecstatic rapport of the Being-for-itself ${ }^{3}$ to the past and future and the Husserlian conception of the absolute flux of consciousness will be found to imply a transcendental factor which in the case of Sartrean temporality seems to be the annihilation (néantisation), described as something not real, of the Being-initself-the source of appearance of the Being-for-itself in the world-and also of the 'ontological' nature of the Being-for-itself (Sartre, 1943, 173).

Therefore we can talk about an underlying transcendence in the Sartrean temporality inasmuch as this temporality is thought of as not existing in terms of being in objective sense but as merely the mode of 'being' of a purely subjective consciousness-Sartre's Being-for-itself-which is always ecstatically in advance of itself. In this respect, it is already 'behind' itself in present actuality and its temporality cannot be conceived but as a passing annihilation that implies by necessity a past.

The ecstatic dimension of the temporality of the Being-for-itself is described as the 'distance' to itself and this 'distance' is nothing describable in objective terms, nothing that can be predicated as being in itself. It is simply a null, an evanescence which 'is been' as a separation and it is taken to define in ecstatic unity the rapport of the Being-for-itself with its past and future, grounding this way in an endless

3 The Sartrean notion of the Being-for-itself, in contrast to the Being-in-itself (En-soi), can be roughly taken as implying a kind of transcendental leap out of the 'inwardness' of consciousness. 
regression the appearance of any consciousness as 'being already born'4. The past, as something not posed in front of the Being-for-itself, is ecstatically already behind and out of its thematic field to the extent that it is no more expecting to be 'clarified.' From a certain viewpoint these ideas seem to be implied by the notions of retention and protention and generally Husserl's description of the intentional forms of absolute temporal consciousness something that I will comment further along with the general Husserlian approach to the transcendental ego.

At this point it should be stated that the 'background' of the existentialist treatment of time (in Heidegger and Sartre) lies in fact in Husserl's phenomenology of inner time consciousness (Husserl, 1966). It was on the basis of Husserl's phenomenological insights about the temporal flux of consciousness that Heidegger and Sartre affirmed the priority of the future over the past and the present, even though Husserl eventually came to espouse the living present as the primary source of all living being and the mode of presence of the absolute ego in the world (Husserl, 2001b, 4). Nevertheless there is no doubt that both Heidegger's and Sartre's approaches to the treatment of temporality have Husserl's lectures on time consciousness as their basis. Yet, given the subtleties and ambivalences that come with the way these concepts are dealt with, there are cases, like V. Thomas' (Thomas, 1990) in which it is improperly argued that existentialists developed Husserl's insights in new ways and translated his epistemological language into an existential language (Thomas, 1990, 347-348). As I will discuss and show in the sections that follow, Husserl's language on the question of the nature of transcendental ego far from having any epistemological leanings, as it is virtually a priori founded, underlies in many respects the existentialist approach.

Heidegger's approach to the nature of Dasein will also find its due assessment (within the scope of this article) in the coming sections, the whole undertaking leading to the position that inner temporality and its origin holds the key to clarifying the affinities and divergences in the respective positions on the character of the absolute ego. It is true that although Heidegger shared Husserl's conception of

\footnotetext{
4 The last consequence may lend itself as a meaningful answer to the existentialist questions of life and death. Assuming that my consciousness is, as any other subject's, a temporal one it turns out that the finiteness of my existence is not the finiteness of myself that I experience but it is always the finiteness of others. I can never experience my own first moment (birth) and last moment (death) but only as ecstatic moments (or in Husserlian terms as intentional moments of the absolute flux of consciousness); that is, in P. Merlan's words: "in the modus of having already forgotten birth and still expecting death... Always I have already had time, and always shall I still have time." (Merlan, 1947, 36-37).
} 
time-consciousness as the framework in terms of which experience is possible, and although he also shared Husserl's commitment to the absoluteness of temporality, he relocated temporality from time consciousness to the structure of Dasein as 'agency' vis-à-vis the world. The finite and futural temporality of active selfunderstanding supplants the Husserlian infinite and now-oriented time of selfconsciousness (Brough, 2006, 132-133). Yet, even though Heidegger grounded the now, as the reference point of consciousness, in the future, as the reference point of self-understanding, in contrast to Husserl's conception of the primal now as the point of orientation for our conscious lives, my intention is nevertheless to argue for a significant convergence between them in terms of inner temporality as a constituting immanent factor pointing to an essentially egological origin.

\section{RECOURSE TO A TRANSCENDENCE BY INFINITE REGRESSION}

A major ambivalence generated by the phenomenological attitude toward objective reality is that of the possibility of an infinite regression due to the reflecting activity of consciousness. Put in more concrete terms, one is faced with an indefinitely proceeding sequence of reflections in the mode reflecting-reflected by virtue of admitting to a self-constituting origin of phenomenological reduction. A particular instance in which Husserl took this infinite regression into account is the foundation of the irreal (not objectively real) nature of objectivities as intended senses in Erfahrung und Urteil (Husserl, 1973). Sense as intended content is thought, in terms of a formal ontology, to be in extremis an object in the sense of a 'somethingin-general' possibly devoid of any 'thingness content,' or at least prone to an objectification and accordingly made substrate of a judgment and of a predicative act of identification and explication. It follows that it may acquire a sense of a secondlevel which means that it is objectified in having a sense and by being objectified eo ipso it possesses a sense. Then one is led to an infinite regression insofar as the sense of a sense (the latter as objectified) can in turn become an object, then a have a sense of its own and so on. Consequently one can deduce that sense cannot be a real (reelles) component of an object as it 'is' always in a non-eliminable deficiency with regard to its own ontification (Husserl, 1973, 269).

In the Bernau manuscripts (Husserl, 2001a, 184-188) Husserl was faced with the difficulties emanating from this kind of infinite regression, yet he tried to circumvent the problem by searching the possibility of talking about a process of living experiences (not of temporally constituted experiences of the first degree) which 
advances as a living flux (Lebensstrom) without being itself knowable as a temporal object and constituted through a temporal constitution. For example, talking about an incident of sound, then the living-experience flux in which the appearance of sound is given can be taken as an individual object itself having its own time-interval of duration and also its own temporal position in the phenomenological time (this latter as contrasted to objective physical or psychophysical time). Then one can talk about the flux of concrete living experiences as an individual object in terms of its givennesses which points to yet another flux through which it 'appears' in reflection which can again become a temporal object with its own modes of givennesses and this way one can enter a regression in infinitum that is obviously an absurdity. The way out of this absurdity was thought to be the arduous (and ultimately unanswerable) task of bringing into evidence a primary living process which is really not a consciousness process, at least not a consciousness process which can be known as a process in phenomenological time. In such case it is questionable what else could a primary living process be other than a first-degree immanent experience within a self-constituting temporal process in a way that even though it is thought of as irreducibly original it may be only conceivable as 1) a first-degree immanent experience in a first phenomenological time, and also as 2) a self-referring process of consciousness knowable by consciousness itself in a second phenomenological time (Husserl, 2001a, 188). Husserl had similar concerns about the absurdity of an infinite regression in considering the intentional modes of retention and protention of consciousness, the former one thought of in terms of fulfillments of previous retentions generating thereby new protentions and so long in infinitum. In the face of these absurdities Husserl took the first-degree phenomenal time as only possible by means of an inner second-degree transcendental time having as a last transcendental occurrence the infinite process itself which is by itself consciousness of a process, termed a primary living process (Husserl, 2001a, 27-30).

In the bottom line what becomes object of reflection has to be in a temporal form and has also to be identically the same in the flux of the multiplicities of its givennesses. Then if the primary process (Urprozess), as it is usually termed in the Bernau Manuscripts the equivalent of the absolute ego of consciousness, is a temporal one we might turn our reflective'glance' to the givenness of its phases in the scheme original impression-retentional degradation, and as the givenness of these phases would stand as a temporal sequence itself upon which we could turn anew our reflection and so on in infinitum we would end up in an infinite regression of reflections each one meant as a consciousness-of. 
Consequently one should plausibly seek a clarification of the essence of 'being' of an Urprozess as preceding reflection. Husserl asked how in such a case one can think of a primary flux, perceived as a temporal one, yet one which could nonetheless not be made consciousness of a temporal flux nor of a phenomenological perception (Wahrnehmung). In the face of this grave difficulty he proposed the possibility of a process in which, for example, the sequence of an event with its generated 'repercussions' may find itself in the continuous unity of consciousness and in the phenomenological time without this process having the privilege of being intentionally 'noticed' or reflected upon. In that case, except for the already apprehended temporal objectivities could be also constituted in the background fully 'unnoticed' objectivities randomly and not by necessity. In the final count the question is reduced to whether, in the strictest sense, each concrete living-ego may have the character of a consciousness-of and thus be necessarily objectivityconstituting. Further, the question is whether the living-ego can be a sort of apprehension, namely an apprehension in the usual sense of an attentive formation, or possibly an apprehension in the widest sense of forming an intentional object where this intentional object cannot be identified with the act of apprehending, namely with the intentional experience as consciousness of it (Husserl, 2001a, 198-199).

In view of these core issues Husserl asked in the Bernau Manuscripts whether the temporality of the subject of consciousness is, in principle, due to genetically induced apperceptions in which unknown processes incur which are not temporally constituted themselves. However this implies that even with the supposition of a succession of genetically induced apperceptions we can still reach an impasse insofar as one can hardly constitute a sequence of apperceptions in which the identity of each one could be preserved in sinking to the past without presupposing an unknown process in consciousness 'preceding' the genetically induced succession of apperceptions.

In this sense the question remains essentially open as to how a transcendental, time-constituting process can be apprehended by any other means except by reflection. Evidently if object-contents exist and flow as a continuous sequence ${ }^{5}$ the

In a mathematical sense the term continuous sequence is a contradiction of terms. However the term sequence must be taken here in a Husserlian meaning that involves temporal succession and the a priori intentional forms of retention-protention making possible the continuous flow of events as immanences within consciousness. 
question posed in the final count concerns the founding possibility of apprehension of these contents and of their flow. This process cannot supposedly consist in phenomenological perceptions upon which we can reflect since in this way these perceptions and their hypostasized contents are to be objects in a second timeconstituting process in an open-ended horizon.

It turns out that this must be a kind of process which not only cannot be presented in reflection as temporally given but there must also be the evidence that this process was constituted prior to any reflection and that being and constitutedin-being are in it inseparable, in a way that this process may be knowable just like any object of phenomenological perception as temporally constituted without the necessity of an intentionally turned 'regard' (Husserl, 2001a, 205-206). However, one may put into serious doubt the validity of a temporal expression of the kind 'this was constituted prior to any reflection,' as it seems utterly meaningless without the attentive regard of a time-constituting consciousness. It follows that it is either nonsensical to talk about the possibility of a process prior to any reflection or else generate an infinite chain of circularities founded on the very presence of a temporality-constituting consciousness. In either case there seems to be no way of eliminating the primary source of an infinite chain of regressions associated with the reflective regard of a temporal ego other than by admitting to the transcendental character of an absolute subjectivity knowable only as its 'mirror-reflection image' in temporal objectivity. As it is well-known this subjectivity was already meant by Husserl in the Phenomenology of Inner Time Consciousness as the absolute ego of consciousness (Husserl, 1966, 74-75).

A distinct approach in view of the trappings of an infinite regression was taken by Sartre in Being and Nothingness (L'être et le néant), by positing the act of reflection as correlative to the manifestation of the ecstatic nature of the Being-foritself and based on an ontology of temporality (Sartre, 1943, II). On these grounds one must take account of the Being-for-itself as presenting itself to the being-inthe-world in terms of its original dispersion with regard to the Being-in-itself and in view of the implementation of the three temporal ecstasies past-present-future. As Sartre pointed out 'being' out of itself and in the most close intimacy to itself the Being-for-itself is ecstatic because it must search its being elsewhere, namely, in the reflecting which is being reflected and in the reflected which poses itself as reflecting (Sartre, 1943, 188).

In a certain sense the Being-for-itself by 'continuously' being what it is not, incorporates the quasi-duality reflecting-reflected since the motivation of reflection 
consists in the simultaneous tentative of objectification and interiorisation, this latter term meant as the tendency of the Being-for-itself toward the 'interiority' of its being. Sartre transposed in effect the non-eliminable residuum reflecting-reflected of a temporal ontology to the ecstatic nature of the Being-for-itself in the sense that this latter is meant as "the being which flees itself while being what it is in the mode of not-being and which flows on while being its own flow, which escapes between its proper fingers...” (Sartre, 1992, 153).

Consequently the Being-for-itself becomes a givenness which is what it is as a unity in front of a 'gaze.' Yet Sartre reached an ontological impasse in the claim that the Being-for-itself tends to be its proper foundation by capturing and dominating its proper elusiveness as an 'interiority' of itself, in other words by being its proper elusiveness instead of temporalising elusiveness as such. This would ultimately result in a failure the realisation of which is precisely the reflection (Sartre, 1992, 189), which means that Sartre could not avoid the same Husserlian trap. On the other hand, the ontological Being-in-itself cannot found anything not even itself for in that case it would render unto itself the modification of the Being-for-itself and consequently would be a foundation of itself only on condition of not further being Being-in-itself.

A phenomenologically motivated alternative would be to insist on the existence of a pre-reflective self-consciousness which, as previously argued, was thought in the Bernau Manuscripts as being 'excluded' from its own self-reflection, though only by a somewhat circular approach. In this regard Sartre wrote: "There is no infinite regression here, since a consciousness has no need at all of a reflecting higher-order consciousness in order to be conscious of itself. It simply does not posit itself as an object" (Sartre, 1960, 45). This means the pre-reflective self-consciousness is not transitive in relation to the state (of) which it is aware. It is, as Sartre put it, the mode of existence of consciousness itself. However, this does not mean that a higher-order representation is impossible, but merely that it always presupposes the existence of a prior non-objectifying, pre-reflective self-consciousness as its condition of possibility. Sartre thought accordingly that it is the non-reflective consciousness which renders the reflection and probably any higher-order representation of it possible.

In Heidegger's existentialist version the unfolding of an infinite regression of reflections of the Husserlian ego unto itself is addressed by reducing to the ekstatic nature of Dasein as a realization of its taking care within the world and it is indissolubly linked to its temporality inasmuch as 
The genuine being of Dasein is temporalness. After all, Dasein is the 'time' that exists in the mode of temporalness; the being of Dasein is temporality. In what way 'time' exists and how it is temporal, we can understand only by looking at the true being of 'time.' (Heidegger, 2011, 51)

The question of the inexhaustible possibility of reflections of Dasein unto itself is associated with the roughly equivalent question of the possibility of a complete accessibility of Dasein whose completion cannot be taken but as a moment in the 'break up' of the connecting process of experiences and events and in the cessation of the acts on account of which the being of Dasein is no more 'there.' In this view and true to the world-founded nature of Dasein, Dasein is taken in advance as given-in-the-world and inquired according to what still exists there as its available givenness or not. Even in taking Dasein's reflection unto itself as a demonstration of anticipating resoluteness (vorlaufende Entschlossenheit), which is in turn a mode of Dasein's care (Sorge), one would fall again to the trap of temporality which enables the unity of caring for, something that implies temporality may be revealed in its three ekstases past-present-future as the meaning of the caring for.

In Being and Time (Sein und Zeit) Heidegger was very cautious as to the content one might give to the temporal character of the 'glimpse' of Dasein (in terms of the three ecstatic directions) to a time-point and ultimately unto itself. His position was that the time-point is non-existent as an ontologically autonomous being as it is rather the 'glimpse' of Dasein along the three directions of view and it was essentially thought as a proper possibility of time itself. Even as the question of an 'ontology' of temporality seems inherently associated with the conception of both the Husserlian absolute ego and the Heideggerean Dasein, a key difference between the respective approaches seems to be that while the former reaches out for a transcendence out of this world by relying on the absolute ego of consciousness as the primary source of constituted temporality, the latter associates everything pointing to an inner transcendental source of temporality to a temporal existence within-the-world oriented to the future as a primary manifestation.

\section{THE RELATION OF THE EGO TO THE WORLD AS THE PRIMITIVE SOIL OF EXPERIENCE}

The relation of the transcendental ego to the world taken in its most primitive sense as the primary soil of experience is a main divergence between Husserl's notion of the ego, Heigegger's view of Dasein, and with some nuances the existentialist position of Sartre. 
One of Husserl's earliest references to the transcendence of the ego with regard to the world at large can be found in his probably most influential purely phenomenological work, Ideas I, where the absolute consciousness is conceived as a residuum of the annihilation of the world, characteristically expressed in the title of the paragraph: Das absolute Bewußtsein als Residuum der Weltvernichtung (Husserl, 1976, 103; 1983, 109).

More specifically Husserl claimed that while the being of consciousness or of any stream of mental processes would be modified by an annihilation of the world of physical things, yet it would not be touched in its own proper existence. This means that while in an annihilation of the physical world some of the ordered concatenations of experience and consequently certain corresponding concatenations of theoretical reasoning would be eliminated, the same would not hold for concatenations of mental processes in regarding the stream of consciousness (or of any mental process) in its full generality as comprising also the mental processes of an ego. In conclusion no real being presented and legitimated in consciousness through appearances is necessary to the being of consciousness itself or generally to the being of any stream of mental processes as lived experiences.

Immanental being is therefore indubitably absolute being in the sense that by essential necessity immanental being nulla 're' indiget ad existendum. In contradistinction, the world of transcendent 'res' is entirely referred to consciousness and, more particularly, not to some logically conceived consciousness but to actual consciousness (Husserl, 1983, 110).

The Husserlian ego regarded as the ultimate foundation of temporality should not be regarded as a simple substrate in the simple sense of an unqualified immanent unity underlying the multiplicity of mental processes. Instead it must be thought of as a unity-in-act whose essential nature without its auto-alienation in the act of objectification (through reflection) is totally inaccessible. Moreover since the condition of individuality and existence is inseparable from a conception of temporality as an objectivity, one cannot attribute to the ego the predicates of existence and individuality thereby essentially banning it out of this world. It is notable though, in J. Patočka's view, that the Husserlian ego cannot be identified with the extreme idealist version of Spinoza's intellectus Dei infinitus nor can lead to solipsistic ambiguities as it functions in concrete terms in the flux of each individual's consciousness and intersubjectively in all existing ones (Patočka, 1992, 168). Also one should be careful enough to note that even though human ego considered in its purity is for Husserl a complex of absolute being 'impervious' 
or 'bounded' to anything spatio-temporal, yet it is taken along with the human being in general as subordinate single realities to the whole spatio-temporal world (Husserl, 1976, 105-106). This means that even in taking spatio-temporal world as a mere intentional being referred to the absolute existence of a consciousness by being posited in its experiences and reducible to the identity of motivated multiplicities of appearances, the existence of the absolute ego is conceived as included in the spatio-temporal world in a subordinate sense in spite of the fact that the ego by essential nature does not partake of any spatio-temporally defined objective processes.

Heidegger, on the other hand, took an approach to the origin of Dasein that is firmly and unquestionably rooted in the world of phenomena. In Being and Time it is firmly stated that certain determinations of the being of Dasein (i.e., authenticity, inauthenticity or the modal indifference to them) must be seen and understood as a priori grounded on that constitution of being called being-in-the-world. In this connection 'being together with' the world should be interpreted in terms of the factor of the being-in of Dasein which in turn cannot be understood but as something existential in a sense further to be explained and certainly not as relating to the objective presence of material things in the sense of a spatial 'in one another.' In Der Begriff der Zeit, Heidegger referred to the being-in as expository and as having the character of discoveredness. In a certain sense being-in is described as possessing the mode of being of a throwing into the world where in caring about the world Dasein cares about itself concerning its immediately next possibilities. In Heidegger's characteristic phrase the being-in of Dasein is in the actual present a caring encounter with the world („Das Insein des Daseins ist ein besorgendes in die Gegenwart Begegnenlassen der Welt“) (Heidegger, 2004, 100).

It is crucial in the Heideggerean outlook to understand the facticity of one's own Dasein as ontologically totally different from the factual occurrence of a material-objective thing, e.g. of a metal object, in that Dasein may have its own 'being-in-space' based on the being-in-the-world in general but meant in the sense of its dispersion within the world. More concretely, the ways of the beingin of Dasein have the kind of being of 'taking care,' this latter key Heideggerean concept ontologically meant to designate the being of a possible being-in-the-world. In other words as the being-in-the-world of Dasein cannot be separated from its being toward the world as essentially 'taking care of,' the being of Dasein can be dispersed in the world in definite ways, for example, having to do with something, creating something, ordering and taking care of something, using something, giving 
something up, asking about something, finding out, determining, (eventually) knowing (Heidegger, 1986, 56-57).

Consequently the Heideggerean Dasein even in assuming an essential nature non-eliminable in terms of a spatio-temporal presence in the world, it is ontologically knit to the world in such ways that it cannot exist otherwise but in the specific modes of being 'thrown' and 'dispersed' to the world. In contrast the Husserlian ego, totally inaccessibly without some kind of retention to its objectified mirror-reflexion, is conceived as not only transcendent to any spatiotemporal reality but by essential nature as deprived of any 'empathy' with the world the letter taken in the sense of an original pre-phenomenological field of experience.

If the relation of Dasein to the world is established by its essential mode of being in the world, the possibility of transcendence of the Being-for-itself is founded, in the Sartrean approach, in the facticity of the world of phenomena. This means that even though the foundation of the Being-in-itself cannot be obtained through its ontological existence in the spatiotemporal world (as it is annihilated to the the Being-for-itself), the Being-for-itself is defined to exist as such, namely as a pure contingence in the world to the extent that it 'contains' something of which it is not the foundation which is its presence in the world (Sartre, 1943, 115). I will come back to these conceptual affinities in Section 5.

These taken into account we should not miss the point that for all the divergences and similarities in the respective approaches of Husserl, Heidegger and Sartre to the nature of the transcendental ego and its relation to the world there is a crucial question to be discussed in the last section which may serve, partially at least, as a unifying interpretational factor. This is the question of inner temporality and the way it may shape the discussion on the transcendental character of the absolute ego.

\section{A COMPARATIVE LOOK INTO THE HUSSERLIAN EGO AND THE HEIDEGGEREAN DASEIN}

As it is well-known to phenomenologists Heidegger placed the phenomenology of time and temporality at the center of the content of Being and Time, even if the ontology of being in general on the basis of the temporality of the being of Dasein is quite distinct from Husserl's doctrine: “...we need an original explication of time as the horizon of the understanding of being, in terms of temporality as the being of Da-sein which understands being" (Heidegger, 1996, 15). A key point of their 
diverging views, at least on the fundamental question of being, was Heidegger's insistence that the phenomenological clarification of being (which Husserl proposed) should be extended to the being of the transcendental subject itself in the sense that the problem of Being should be directed toward the constituting and the constituted alike. This is a question presumably left by Husserl in an ontological vacuum. Yet for all the differences in the respective approaches, particularly evident from the time of Husserl's article on Phenomenology in Encyclopaedia Britannica (1929), S. Crowell thinks in Husserl, Heidegger, and Transcendental Philosophy: Another Look at the Encyclopaedia Britannica Article that a significant rapprochement between Husserl and Heidegger, leaving neither totally unrevised, may become thinkable (Crowell, 1990, 518).

As mentioned in the Introduction the inclusion of the Heideggerean Dasein in a review of the general notion of the ego of continental philosophy might strike someone as far-reaching given that the concept of facticity associated with Dasein, insofar as this is inquired with respect to, on the basis of, and with a view to the character of its being, essentially leaves the concept of pure ego out of its ontological field at least in the sense the ego is conceived in Husserlian phenomenology ${ }^{6}$.

For Heidegger there cannot exist a pure ego in isolation of the world and in his own words in Ontology-The Hermeneutics of Facticity it would be a fundamental misunderstanding if in the reference to Dasein "which is in each case our own, a directive was heard to become [...] fixated on vacantly brooding over an isolated ego-like self." (Heidegger, 1999, 25). Yet the modes of existence of Dasein, namely the possibility of its self-alienation within-the-world and above all the fundamental phenomenon of facticity, which is temporality as an existential condition and not as a category, provide sufficient motivation to include also the Heideggerean Dasein in the present discussion. Indicative of the inherent link between temporality and the essence of Dasein are the following two quotations of Heidegger's in The Basic Problems of Phenomenology. "The Dasein is intentional only because it is determined essentially by temporality. [...] How these two characters, intentionality and transcendence, are interconnected with temporality will become apparent to

6 For example concerning the key phenomenological notion of intentionality, Heidegger claims in The Basic Problems of Phenomenology that it is not the case that intentionality is first related to the ego as its generating pole and then from there it goes to the object but rather that by means of intentionality itself is the self in its wholeness disclosed to us. To intentionality belongs not only a self-directing toward and not only an understanding of the being of the object toward which it is directed in terms of the content of this very act but also the unveiling of the essence of the self in its actual enactment. See further (Heidegger, 1982, 158-172). 
us." (Heidegger, 1982, 268) and "We know, however, that this self-direction toward something, intentionality, is possible only if the Dasein as such is intrinsically transcendent. It can be transcendent only if the Dasein's basic constitution is grounded originally in ecstatic-horizontal temporality."(Heidegger, 1999, 314).

Further, Dasein is described as 'being' ahead of itself, that is, as projecting itself upon its potentiality-of-being before going on to any mere consideration of itself (Heideger, 1996, 373). It is 'thrown in the world' and in 'taking care of' Dasein is disclosed as a There. As being-in-the-world it has always expressed itself already, while being-together-with-others means that it keeps itself in average interpretedness which is articulated in discourse and expressed in language. In the final count discourse is itself temporal since all talking about.., of.., or to.., is grounded in the ecstatic unity of temporality.

Insofar as Dasein enters into the discussion as the ultimate bastion of the question of being we may see some fundamental similarities and also some divergences with the Husserlian ego taken as the ultimate transcendental source of the objective unity of being in the Life-World ${ }^{7}$. One can thus point to the advancement of Dasein ahead of itself as bearing a common transcendental origin with the intentionality exhibited by the Husserlian ego to the extent that intentionality as an ego-founded outward directed moment establishes itself on the basis of a reduction performing subjectivity. To the extent that the intentional moments of even a sole consciousness in the world are irreducibly self-founded in this sense, even in a complete annulment of any objects in the world being put anyway into brackets, this can be reasonably taken as implying a certain non-eliminable affinity with the sense attributed to Dasein by virtue of the a priori moment of the latter to project itself ahead of its potentiality-of-being-in-the world.

Clearly a convergence may be founded on a fundamental level in the possibility of grounding both Dasein and the Husserlian ego upon temporality, in accepting however a fundamental difference, namely that while the Husserlian ego manifests itself primarily in the actual present, time as the horizon of the self-understanding of Dasein is aimed toward a future for the sake of which each one acts as he does. In Being and Time the circumspect taking care of common sense is grounded

The Life-World can be roughly described to a non-phenomenologist as the physical world with its ever receding horizon including in an intersubjective sense all knowing subjects in a special kind of presence in the World. More on this in E. Husserl's The Crisis of European Sciences and Transcendental Phenomenology (Husserl, 1962). 
on temporality inasmuch as it makes possible the constitution of a present that awaits and retains. This is the way through which the advancement of Dasein ahead of itself is making itself 'explicit' within the world, namely in the modes of presentifying (Gegenwärtigen) retaining (Behalten) and awaiting (Gewärtigen). In comparison the Husserlian ego is making itself 'explicit' by being self-constituted as a 'mirror' reflexion of its ever in-act subjectivity in the actual now along with the intentional forms of not-yet and just-passed-by. After all Husserl's concept of absolute consciousness as a condition, among other intentional forms, of the possibility of the awareness with regard to any object whatsoever was accepted by Heidegger and given the new name of the ecstatic-horizonal unity of temporality which 'carries Dasein away' and thereby constitutes Dasein's 'transcendence,' its stepping over to a world, its 'being outside itself' in a world (Brough \& Blattner, 2006, 131).

In a sense Heidegger established temporality as a way through which Dasein is making itself expressible in addressing what it takes care of. As it turns out, this addressing and 'discussing' by which it also interprets itself is grounded in making out a present and it is only possible through it (Heidegger, 1996, 373-374). Although temporality as ecstatically open and horizontally constitutive of the clarity of the 'there' may be in these terms recognizable, nevertheless Heidegger did not preclude the possibility that primordial temporality as such as well as the origin of expressed time may remain unknown and unconceived (Heidegger, 1996, 375). Therefore we have on the one hand a temporality constitutive of the clarity of the 'there' as the means of making Dasein expressible in taking care of and in being-togetherwith things at hand, and on the other hand the origin of temporality which is only expressible by temporalizing itself in the expressed time while standing in itself virtually unknown and unconceivable. In fact the ecstatic unity of temporality, the unity of the 'outside-itself' in the raptures of the future, the having-been, and the present, is the condition of the possibility that there can be a being that exists as its 'there.' Taking the whole constitution of the being of Dasein as the unified ground of its existential possibility, ecstatic temporality clears the 'there' primordially and it is the prime regulator of the possible unity of all essential existential structures of Dasein. It is only in terms of the rootedness of Dasein in temporality that we can gain insight into the existential possibility grounding the fundamental constitution of the being-in-the-world.

As already discussed the corresponding Husserlian transcendental ego constitutive of temporality and consequently of spatiality (the latter meant as a temporally fulfilled objective whole) is temporalized by objectifying itself in 
the unity of each one's temporal consciousness. Insofar as the absolute ego can be known in objective temporality only as a mirror reflexion of its transcendental self, it is bound to remain a-temporal, unobjectifiable and for that reason absolutely impredicative ${ }^{8}$. Yet, while the Heideggerean Dasein is attributed with an ecstatic moment that projects its presence in the world as caring about its 'being' in beingwith-other-beings, the Husserlian absolute ego is completely impersonalized, extraneous to the outer world and obscure and so it remained to the end in spite of Husserl's painstaking efforts in Bernau manuscripts and later to elucidate its 'ontic' character trying at the same time not to get trapped in a maze of circularities.

For Heidegger it is on the basis of the horizontal constitution of the ecstatic unity of temporality that something like a disclosed world belongs to the being which is always its 'there' (Heidegger, 1996, 334). This means temporality temporalizes itself as a future that makes present in the process of having been which is in a certain sense reminiscent of the double form of the intentionality of consciousness in Husserlian terms: On the one hand, there is the transversal intentionality as a priori binding any original impression to the attached protentions and retentions, that is, by retaining what is registered in consciousness in the present now by virtue of having been already 'anticipated,' and on the other, there is the longitudinal intentionality by which a stored memory can be retrieved by secondary memory in the present now of consciousness by having been retained as a continuously descending sequence of retentions constituted as a whole within the objective unity of the stream of consciousness. It is notable that in Heidegger temporalizing does not mean a 'succession,' in the Husserlian sense, of the ecstasies in the sense that

8 It is worthwhile to mention here D. Zahavi's view (Zahavi, 2011, 322-323) and elsewhere that the Husserlian transcendental ego does not and cannot be a unifying or synthesizing actor, at least in an active way, in the unity of temporal consciousness, consequently one should talk about a continual substratum of the egoless streaming that founds it. To strengthen his argument Zahavi refers, except for certain passages in the Phenomenology of Intersubjektivity III and the Formal and Transcendental Logic where Husserl points to a pre-egoic factor grounding the passivity of the stream of consciousness, to Husserl's well-known Phenomenology of Inner Time Consciousness in which he purportedly gives no reference to the ego as the ultimate unifying or synthesizing agent. However this is a position that can be refuted insofar as we may take Husserl's explicit reference to an absolute subjectivity, which constitutes as a continuity of apparitions a present to which it belongs and a past which also constitutes (not constituted) and to which it also belongs, as referring precisely to the transcendental ego (Husserl, 1966, 75). Besides, there is no possible way to think of an egoless streaming in the sense of a passive streaming which is beyond the influence of the ego without generating an endless recurring sequence of reflecting-reflected which, in spite of Husserl's lasting attempts to circumvent, was and is still one of the thorny issues facing the phenomenology of temporal consciousness. See also C. Macann's views on the impossibility of a phenomenological constitution of the transcendental ego (Macann, 1991). 
the future is not later than the having-been and the having-been not earlier than the present. The unity of the horizontal schemata of future, having-been and present is grounded on the ecstatic unity of temporality. These given and notwithstanding the essential differences in the description of the Husserlian ego and the Heideggerean Dasein it is critical that in both approaches the capital issue of the original source of temporality is left in relative vagueness probably on account of the extreme difficulty in shaping a meaningful discourse on this question.

The difficulty can be seen, for instance, in Husserl's description of the essence of absolute ego as a nunc stans (never-in-being) which is a contradiction in terms and also in his appeal to pre-predicative intentionality structures termed so to the extent that they 'anticipate' without by essential necessity being actually oriented to temporally constituted instances, in other words without being oriented to actually existing objects of spatio-temporality. In this sense one may claim that intentionality of consciousness defines a domain of real possibility anterior to actuality (Heelan, 1988, 12; Tieszen, 2011, 114-115).

The difficulty of talking about the original source of temporality may be also found in the Heideggerean description of Dasein in terms of the non-ontological qualifications of 'taking care' or of 'being thrown into existence' referring to the outside-of-itself of the ecstatic unity of temporality. Both Husserl and Heidegger talked about temporality essentially in the context of constituted objectivity and of being-in-the-world respectively, considering the description of a temporal duration or of temporal unity as only a being-in-the-world discourse where any ante situation is virtually left as a circularities-generating, non-ontological (and therefore impredicative) state of affairs.

\section{THE TEMPORALITY OF SARTRE'S BEING-FOR-ITSELF}

Sartre used the terms of ecstasis and horizon as key concepts of his existential version of phenomenology, and like Heidegger before him, viewed primordial temporality as the foundation for our 'transcendence' or 'openness' to a world. However to the extent that the Heidegerrean conception of Dasein bore a certain

\footnotetext{
9 A very interesting review of the affinities in Husserl's and Heidegger's description of the 'authentic' time (or inner time of consciousness), is presented in (Held, 2007, 336-339) through the fundamental role ascribed to the protentionality of consciousness which, by the way, refutes de facto the aristotelian notion of time as a series of still 'nows.'
} 
influence on him he had eventually to part ways from Husserl's orientation to the lived experience of the now founded on the logic of predominance of the relation subject versus object over that of Dasein versus the world. Yet as it happened also with Heidegger, Sartre was largely shaped by Husserl's phenomenology even though he later came to criticize key Husserlian ideas, among them, Husserl's conception of the transcendental ego as being incompatible with Husserl's definition of consciousness as a unity in objective terms. There is even scholarly research showing the positive influence earlier Husserl's Logical Investigations (Husserl, 1984), played in forming Sartre's approach to basic philosophical problems such as the nature of intentionality, consciousness, and the self, even if it does not seem to me that the relevant arguments are always firmly founded.

In any case, I am going to discuss in the following certain affinities between the Sartrean version of a possible transcendental origin of consciousness and the Husserlian ego. I note at this point certain authors' views on Sartre's presumably non-egological conception of consciousness, namely Zahavi's position in (Zahavi, 2011, 323), that consciousness in Sartre is in no need of a transcendental principle of unification since it is, as such, a flowing unity and Tandon's position in (Tandon, 1998 , 467) on Sartre's 'deconstruction' of the egological conception of consciousness. These views are going to be indirectly addressed and refuted in the following discussion.

Sartre's main divergences from the Husserlian perspective regarding the notion of the absolute ego appeared in The Transcendence of the Ego (Sartre, 1960), almost a decade earlier than the first publication of Being and Nothingness (1943), and concerned precisely the relation of consciousness to the transcendental ego. In more concrete terms, Sartre refused to accept anything, including in the first place the absolute ego $^{10}$, that might be interpreted as a content of consciousness while claiming in a way that sounds familiar with his subsequent clarification of the Beingfor-itself in Being and Nothingness that consciousness is a spontaneity, a pure activity transcending and exhausting itself toward objects which is never self-contained nor

10 In denying the 'existence' of the ego within consciousness Sartre stated in The Transcendence of the Ego: "For most philosophers the ego is an 'inhabitant' of consciousness. Some affirm its formal presence at the heart of Erlebnisse, as an empty principle of unification [...] We should like to show here that the ego is neither formally nor materially in consciousness: it is outside, in the world. It is a being of the world, like the ego of another." (Sartre, 1960, 31). In conclusion he accepted the 'I' (taken simply as a functional version of the ego) as existent and strictly contemporaneous with the world whose existence (that of 'I') has the same essential characteristics as the world (Sartre, 1960, 105). 
it is itself a container as it is always 'outside itself.' Further, as consciousness cannot be isolated from the existing world the question of phenomenological reduction becomes problematic to the extent that such a radical reduction would contract consciousness into its own 'interiority' (Sartre, 1960, 25).

A reason invoked by Sartre for the superfluity or simply the 'non-existence' of the ego with regard to the synthetic and individual totality of each one's consciousness is that consciousness unifies itself concretely by a play of transversal intentionalities which are concrete and real retentions of past consciousness (Sartre, 1960, 39). However the validity of this argument is questionable to the extent that, first, this kind of self-constituted totality is constrained to a circular use of the notion of constituted unity through transversal and longitudinal intentionalities in the first place, and second it may also lead to an infinite regression of the kind reflecting-reflected in the reflective regard of consciousness unto itself,-in spite of Sarte's argument to the contrary. Yet even though Sartre rejected the absolute ego in the Husserlian sense, meant as a transcendental vacuity within the immanence of consciousness, and committed himself to the Being-for-itself induced to the world by the annihilation of the Being-in-itself, one may still argue that there exists no possibility to objectify let alone describe in ontological terms the process of annihilation of the Being-in-itself in its 'modification' to the Being-for-itself, this latter taken in the sense of a consciousness interwoven with the world. This means that as it happens with the Husserlian ego but in a substantially different context there persists a kind of ontological vacuum left over in the process of annihilation of the Being-in-itself toward the facticity of the Being-for-itself, something that, notably, in Sartre's view established the necessity of cogito in Descartes and Husserl. In fact, what rests from the contingency of the Being-in-itself in its transformation to the Being-for-itself is the latter's facticity and its 'unjustifiable' presence in the world in accordance with the interpretation of its existence as a necessity of fact. The result is that the Being-for-itself is the foundation of the being of consciousness but cannot in any way found by itself its presence in the world (Sartre, 1943, 120).

The question of temporality in relation to a performing subjectivity is a vital part of Sartre's analysis of the 'ontology' of the Being-for-itself in Being and Nothingness. In fact, he was led by a consistent critique of the views of Descartes and Bergson to the question of temporality as inherently linked to a unifying act. It is in terms of this unifying act that temporality is conceived as a quasi-multiplicity, a dissociation in terms of a unity, more precisely an irreversible succession (of moments) through temporal unity. In this sense we cannot conceive it as a content 
bearer whose being would be given as an objectivity, for in that case there would be no answer to the question of how this being can be fragmented into multiplicities or how the temporal minima as contents in themselves can be associated within the unity of a unique temporality (Sartre, 1943, 71). Consequently, temporality cannot be thought of in terms of a (static) being but instead should be described as the mode of being which 'is' itself in advance of itself in a way that the temporal conjunctions in advance of and after of can be intelligible for it as reciprocally defined. So long as there is an advancement (essentially an alienation) of being with regard to itself it becomes meaningful to talk in general terms about in advance of and after of. It follows that there can be no conceivable temporality but as an internal structure of the Being-for-itself in the sense that there is no ontological priority of the Beingfor-itself over temporality but rather temporality is the mode of being of the Beingfor-itself to the extent that the latter 'exists' ecstatically with regard to itself. In Sartre's expression, temporality does not exist (in terms of ontological being), yet the Being-for-itself temporalizes itself in existing and moreover, on account of a phenomenologically motivated view of the past, present and future, it cannot exist otherwise than in a temporal form (Sartre, 1943, 172).

Sartre distinguished the ecstatic dimensions of the Being-for-itself with the understanding that the sense of the ecstasy is taken as the distance of the Being-foritself from itself which is not to be considered as something real not even something conceivable as being in itself. In this sense, each ecstatic dimension is a mode through which the Being-for-itself is projected in relation to itself and moreover it is a declination with regard to its being-in-itself separated by a null, something that induces (for the Being-for-itself) a shift of its 'being.' On this account, the Beingfor-itself is ever either in advance of or in retard of itself and it 'is' never in the state of rest with itself. It should not be left without notice that, contrary to certain scholars' view, Sartre put the emphasis on the ecstacy of the present now as Husserl did concerning the ego of absolute consciousness but of course in another context and unlike Heidegger who insisted on the predominance of the ecstacy of the future. Sartre's claim was that it is due to its self-revelation in the present now that Beingfor-itself 'is' its past and as a deficiency of its present self that it is 'haunted' by its future (Sartre, 1943, 177).

In resting on itself the Being-for-itself would 'be' in the a-temporal phase of absolute coincidence with itself, something that is reminiscent in a first reading of the Husserlian notion of a specious present within the immanence of consciousness meant as an a priori articulation at once of original impression, protention and 
retention which by this fact alone annuls the possibility of apprehending and objectifying time instants as ontological beings. On a deeper level it can be seen as posing in another way the question of the transcendental and a-temporal character of the origin of temporality to the extent that in the incessant interplay of reflectingreflected whenever the Being-for-itself is determined as 'being' it is already its past while being at the same time the projection of its 'not-yet-self.' To the question whether this continual change, of a present to a past at once generating a new present, implies an internal change of the Being-for-itself, the answer is that it is the temporality of the Being-for-itself that is the foundation of change and not the change that is the foundation of temporality (Sartre, 1943, 179).

Clearly in admitting to an ecstatic nature of the Being-for-itself it is only by a presupposition of temporality that becomes meaningful a self-refutation of its spontaneity as thematically given (for otherwise it would be perpetually its beingin-itself) and also a refutation of the self-refutation, this latter taken as being-initself a concrete state of affairs. In this sense what is valid for the Being-for-itself as a presence in the world is also valid for temporalization in its totality. It is then a whole never completed, a totality self-refuting and self-evading meant as an extraction of its being-in-itself in the unity of the same emergence, in other words an elusive whole which at the instant of its self-givenness 'is' already beyond. In the Sartrean view temporal consciousness is conceived as the human reality temporalizing itself as a totality which cannot be described as existing but in terms of its own overpassing, meaning that it can never 'exist' as being-in-itself within the limits of an instant for in that case the Being-for-itself would be affirmed as beingin-itself which would contradict its character as never 'existing' in terms of being. These difficulties give ground, at least in part of the secondary literature, for arguing against Sartre's unfavorable position toward the transcendental ego in (Sartre, 1960), as he cannot help but eventually postulate a kind of I (Ich) even on the pre-reflective level in the sense that there must be a more fundamental structure of consciousness which recognizes the body-subject as itself.

Going a step further we may argue that even though Sartre rejected the notion of a pure ego interior to consciousness, the Sartrean Being-for-itself bears in fundamental aspects (primarily by its temporality) certain affinities with the Husserlian absolute ego of consciousness insofar as both are by essence referred to a temporality as a necessary condition of their objectification while by the same measure they are considered as themselves a-temporal yet temporally conceived only as their replicas in the ever regressing relation reflecting-reflected. Further they are 
thought of as the primary reason of the emergence of temporality as the 'fulfillment' of any continuous objective whole (which always refutes its being-in-instantaneity) as they ultimately establish themselves as objectively being-in-the-world, thereby laying the foundation for a deeper discussion with regard to the temporality of intuitive and possibly mathematical continuum ${ }^{11}$. In a phrase characteristic of the convergence of motivations Sartre kept wondering about the incomprehensibility of the intertemporal connections between before and after by asking "What is a succession which waits for unification in order to become a succession?" (Sartre, 1992, 169). Accordingly he questioned how a non-temporal 'being' can generate the unification of e.g., two isolated Being-in-itself in terms of time and place (the before and after) without losing its a-temporality and further on how a non-temporal 'being' can emanate from itself without obliterating itself.

This kind of ontological impasse naturally led Sartre to the same ambivalences faced by Husserl with regard to the endlessly regressing sequence of reflectingreflected. This means the ontological structure of the Being-for-itself cannot be conceived otherwise but as the reflecting referred to a reflected as appearance while being at the same time the appearance of its self-reflection and in reverse mode the reflected cannot but be an appearance for a reflecting without for that reason ceasing to be its own witness. In this view the reflected cannot lay claim to a self-standing foundation inasmuch as it is profoundly altered by virtue of a reflecting consciousness whereas, in turn, the reflection as witnessing cannot be founded as such but through appearances which again deprive it of self-standing as it is necessarily defined by its functioning as reflection-of. Even as Husserl in his later Bernau writings on the phenomenology of time was arguing that the reflected may be given as already existing prior to reflection the supposedly self-standing status of the non-reflected is annulled by the phenomenon of reflection itself. In short, Sartre reduced the separation reflecting-reflected to a nothingness manifest in the 'nullifying' of the Being-for-itself upon reflection, a kind of separation leading in extremis to what Husserl described in quite vague terms as a retention in general interposed between the pure ego and its objectified self upon reflection.

It turns out that the transcendence of a temporally self-constituting subjectivity can, broadly conceived, lend itself as a common guiding principle of the

11 For a discussion of the possibility of foundation of the intuitive and in particular of the mathematical continuum on the phenomenology of inner temporality the reader may consult (van Atten, van Dalen \& Tieszen, 2002; Livadas, 2009). 
respective Husserlian, Heideggerean and Sartrean views to the extent that this kind of subjectivity constitutes temporality in constantly alienating itself from its ontic 'being.' In this sense absolute subjectivity may be taken to 'be' the ultimate origin of a continuous temporal unity which is the sine qua non condition for the immanentization of multiplicities of discrete objects of registered-in perception [including the formal-ontological ones in the sense of Formal and Transcendental Logic; see Husserl $(1992, \$ 24)]$, passively associated within a temporal duration which is founded upon the objectified, homogenous stream of inner temporality. A temporal duration 'fulfilling' an objective continuous whole in the present now of consciousness may, in turn, generate an actual infinity meant as a non-causal, boundless immanent whole in presentational immediacy within consciousness.

\section{TEMPORALITY AS THE ULTIMATE FOUNDATION OF THE EGO OF CONTINENTAL PHILOSOPHY}

Let me draw attention a little more on the Sartrean approach to temporal subjectivity. Reflecting, for instance, on my self now that I draw a line in a piece of paper is in a full and complete sense already a past in terms of a state-of-affairs: I draw a line in a piece of paper whereupon as this state-of-affairs is coming over me at the present now it is already deflected to the state of already-not been (which is in deficiency of its full sense as being-in-itself) by the annihilating property of the Being-for-itself. This way the Being-for-itself is at once before and after itself. By the Sartrean definition of the past and future as ecstatic limits of the temporality of the Being-for-itself one is led to an a-temporality in the absolute coincidence of the Being-for-itself with itself.

The Sartrean a-temporality in the case of absolute coincidence with the Beingin-itself may be thought of, as already discussed, in parallel terms with the Husserlian non-existence of an absolutely self-standing temporal instant since anything intentionally perceived as original impression in present actuality is intentionally tied up to a just-passed-by in retention and a yet-to come in protention (Husserl, 1966, 31-35, 52-53). I also regard Sartre's ecstatic unity underlying the third ecstatic dimension ${ }^{12}$ as pointing in a certain way to the intentional forms (i.e., transversal-

12 A temporal transcendence underlies the third ecstatic dimension, (i.e. being what it is not and not being what it is), insofar as the Being-for-itself in a constant interplay of reflecting-reflected eludes itself in an all-encompassing ecstatic unity in which it is grounded as the ecstatic tendency toward a Being-in-itself inside its ever receding thematic field. 
longitudinal intentionality) exhibited by the absolute flux of consciousness in the Husserlian phenomenology. However here is naturally raised the question of the subjectivity behind the objective unity of temporal consciousness and consequently of any form of constituted unity. It turns out that this kind of subjectivity cannot be comprehensible but as essentially associated with temporality as the form of its objective existence.

As a matter of fact an indirect clue leading to an absolute subjectivity as the original cause of inner temporality may be found in Husserl's description of longitudinal intentionality meant as an intentional form of consciousness establishing the continuous unity of retentions and ultimately the unity of the flux of consciousness as such (Husserl, 1966, 80-83). This has to do with the circular fashion in which the continuity characterizing the unity of a descending sequence of retentions is applied both on the level of constituting and that of constituted thus indirectly pointing to the non-eliminable character of an absolute subjectivity establishing the continuous unity of the flux of consciousness. Ultimately this absolute subjectivity must be a pre-reflective non-objectifiable subjectivity, the ever in-act subjectivity of the continuous unity of temporal consciousness. There is no, strictly speaking, corresponding concept to this kind of absolute subjectivity in Heidegger's analysis of the temporality of Dasein, for Heidegger reduced the original ecstatic temporality to quite perplexing ecstatic forms of existence of the being-in the world. Nevertheless they were both deeply concerned with the phenomenologicalsubjective origins of objective or scientific time (Bernet, 1994, 210).

What is of importance from my point of view is that they both reduced the temporal unity of immanent objects and finally the self-constituting unity of temporal consciousness itself to one or other source of transcendental origin. Heidegger described it as the ecstatic unity of a presentifying Dasein which a priori retains and anticipates (in the sense of tending toward), while Husserl except for the key radical reduction to the absolute ego suggested, on the level of constituted, the a-priori intentional forms of retention and protention of absolute consciousness to provide for the temporal identity of its immanent objects and the longitudinal intentionality for the constitution of the flux of consciousness itself. The transcendence in Heidegger's description of the temporality of Dasein lies, in fact, in the description of its ecstatic temporality as an impetus alienating the being-initself of Dasein from its ontological substance and transforming it into a ceaseless motivation. Temporality is for Heidegger the ecstatic unity of the ecstatic moments of Dasein. 
On account of my arguments in the preceding two sections it follows that Heidegger's notion of ecstatic temporality may be also compatible with the Sartrean view of the ecstatic temporality of the Being-for-itself, something not strange given the influence Husserlian phenomenology had on the philosophical formation of both.

Whatever may be the differences between Sartre and Heidegger in the description of the temporality of the Being-for-itself and Dasein respectively and between them and Husserl concerning the character of the source of unity of temporal consciousness, I consider as most important the following common underlying factor of the respective approaches: This is the 'residual' transcendental subjectivity non-describable in ontological terms, impredicative as an objectivity, which is a constituting (and not constituted) factor of the continuous unity of each subject's temporal consciousness and intersubjectively of all beings-in-the-world.

Such convergence may be defensible insofar as their approaches are irreducibly rooted to a kind of absolute 'being' non-describable in terms of ontological being within temporal objectivity without alienating itself from its mode of 'being' as a time-constituting subjectivity-in-act. Based on the argumentation so far, the Husserlian source of the unity of temporal consciousness, the source of temporality of the Heideggerean Dasein and the 'essence' of the Sartrean Being-for-itself are not susceptible to an ontological postulation except by auto-alienation in objective reflection.

To the extent that we talk about an absolute subjectivity totally inaccessible as such, except in temporal objectivity, we are about to face the question of whether it should be encountered as an immanence of an embodied consciousness totally extraneous to the real objective world. Husserl had thought of the absolute subjectivity of consciousness as the residuum left after an annihilation of the world of physical things in the sense that no real being presented and legitimated in consciousness by appearances is necessary to the being of consciousness itself. This means that while the being of consciousness as an absolute immanental 'being' is by essential necessity not born out of any existing thing of the physical world, a transcendent object of physical reality, on the contrary, is entirely referred to an intentionally oriented consciousness. As claimed in Section 3 consciousness in its purity 'is' a self-contained absolute being to which nothing is spatiotemporally external and, yet, it cannot be contained within any spatiotemporality for in that case it would be temporally objectified and subjected to the laws of causation. It follows that in taking the whole spatiotemporal world, which includes the human ego in the sense of a subordinate reality, as a secondary being posited by an intentional 
consciousness we can reach in extremis the conclusion that the world is constituted by consciousness as something identical arising from motivated multiplicities of experiences beyond which there is nothing to be (Husserl, 1976, 106).

The author tends to side with the Husserlian view of the self-founded 'interiority' of the absolute ego of consciousness even though it cannot be conceived as such except as always being-in-act within the surrounding life-world. Yet if this is a point in which the views of the philosophers dealt with in this article vary, a significant part in it served to point to their convergent approaches concerning the transcendental source of any subjectivity-within-the-world and the terms under which it may be viewed as the source of constituted temporality. In the final count temporality as the ultimate form of presence of the ego in the world is argued to be a unifying contextual factor for addressing the respective philosophical positions.

\section{REFERENCES}

Bernet, R. (1994). La vie du sujet. Paris: PUF.

Brough, B. G., \& Blattner, W. (2006). Temporality. In K. H. Dreyfus \& A. M. Wrathall (Eds.), A Companion to Phenomenology and Existentialism (127-134). Chichester: Wiley-Blackwell.

Crowell, G. S. (1990). Husseri, Heidegger, and Transcendental Philosophy: Another Look at the Encyclopaedia Britannica Article. Philosophy and Phenomenological Research, 1(3), 501-518.

Dreyfus, K. H., \& Wrathall, A. M. (Eds.). (2006). A Companion to Phenomenology and Existentialism. Chichester: Wiley-Blackwell.

Heelan, P. (1988). Space-Perception and the Philosophy of Science. Oakland: University of California Press.

Heidegger, M. (1982). The Basic Problems of Phenomenology. Bloomington: Indiana University Press. Heidegger, M. (1986). Sein und Zeit. Tübingen: M. Niemeyer Verlag.

Heidegger, M. (1996). Being and Time. Albany: State University of New York Press.

Heidegger, M. (1999). Ontology - The Hermeneutics of Facticity. Bloomington: Indiana University Press.

Heidegger, M. (2004). Der Begriff der Zeit. Frankfurt: V. Klostermann.

Heidegger, M. (2011). The Concept of Time. NY: Continuum.

Held, K. (2007). Phenomenology of 'Authentic Time' in Husserl and Heidegger. International Journal of Philosophical Studies, 15(3), 327-347.

Husserl, E. (1962). Die Krisis der Europäischen Wissenschaften und die Transzendentale Phänomenologie (Hua VI). Den Haag: M. Nijhoff.

Husserl, E. (1966). Vorlesungen zur Phänomenologie des inneren Zeibewusstseins (Hua X). Den Haag: M. Nijhoff.

Husserl, E. (1973). Experience and Judgment. London: Routledge \& Kegan Paul.

Husserl, E. (1976). Ideen zu einer reinen Phänomenologie und phänomenologischen Philosophie, Erstes Buch (Hua III/I). Den Haag: M. Nijhoff.

Husserl, E. (1983). Ideas pertaining to a pure phenomenology and to a phenomenological philosophy: First Book. The Hague: M. Nijhoff.

Husserl, E. (1984). Logische Untersuchungen (zweiter Band, erster Teil). Den Haag: M. Nijhoff. 
Husserl, E. (1992). Formale und Transzendentale Logik, Band XVII. Hamburg: Felix Meiner Verlag. Husserl, E. (2001a). Die Bernauer Manuskripte über das Zeitbewusstsein (1917/18). Dordrecht: Kluwer Acad. Pub.

Husserl, E. (2001b). Späte Texte über Zeitkonstitution, Die C-Manuscripte (Hua Materialien VIII). Dordrecht: Springer.

Keller, P. (1999). Husserl and Heidegger on Human Experience. Cambridge: Cambridge University Press.

Levy, L. (2016). Intentionality, Consciousness and the Ego: The Influence of Husserl's "Logical Investigations" on Sartre's Early Work. The European Legacy, 21, 511-524.

Livadas, S. (2009). The Leap from the Ego of Temporal Consciousness to the Phenomenology of Mathematical Continuum. Manuscrito, 32 (2), 321-357.

Macann, C. (1991). The Impossibility of a Phenomenological Constitution of the Transcendental Ego. In Presence and Coincidence, Phaenomenologica, 119 (41-56). Dordrecht: Kluwer Acad. Pub.

Merlan, P. (1947). Time Consciousness in Husserl and Heidegger. Philosophy and Phenomenological Research, 8 (1), 23-54.

Patočka, J. (1992). Introduction à la phénoménologie de Husserl. Grenoble: Ed. Millon.

Sartre, J. P. (1943). L' être et le néant. Paris: Ed. Gallimard.

Sartre, J. P. (1960). The Transcendence of the Ego. New York: Hill \& Wang.

Sartre, J. P. (1992). Being and Nothingness. NY: Washington Square Press.

Tandon, A. (1998). Sartre's Non-Egological Conception of Consciousness. Indian Philosophical Quarterly, 25(4), 467-476.

Thomas, C. V. (1990). The Development of Time Consciousness From Husserl to Heidegger. In T. A. Tymieniecka (Ed.) The Moral Sense and Its Foundational Significance: Self, Person, Historicity, Community. Analecta Husserliana, 31 (347-360). Dordrecht: Springer.

Tieszen, R. (2011). After Gödel: Platonism and Rationalism in Mathematics and Logic. Oxford: Oxford University Press.

Van Atten, M., van Dalen, D., \& Tieszen, R. (2002). Brouwer and Weyl: The Phenomenology and Mathematics of the Intuitive Continuum. Philosophia Mathematica, 10(3), 203-226.

Zahavi, D. (Ed.). (1998). Self-Awareness, Temporality, and Alterity. Dordrecht: Springer.

Zahavi, D. (2002). The Three Concepts of Consciousness in "Logische Untersuchungen". Husserl Studies, 18, 51-64.

Zahavi, D. (2011). Unity of Consciousness and the Problem of Self. In S. Gallagher (Ed.), The Oxford Handbook of the Self (316-338). Oxford: Oxford Univ. Press.

Zahavi, D. (2012). The Time of the Self. Grazer Philosophische Studien, 84, 143-159. 